\title{
Corporate Reputation and Brand Architecture: the Debate
}

Dalija Hasanbegović*

Abstract:

This paper argues that for organizations with a branded identity structure investing in corporate reputation is not a waste of scarce resources, but a wise strategic investment that earns significant present and future economic and non-economic returns for a company. In the global market of the 21 st century, corporate reputation provides a number of intangible benefits: it permits stakeholders to asses a firm's ability to deliver valued products; it indicates past interactions with a firm's stakeholders; it improves a firm's ability to recruit and preserve its primary stakeholders; along with delivering tangible (financial) benefits by enhancing a firm's ability to do better than its competitors, thus expanding its profits and revenues. These tangible and intangible benefits of favorable corporate reputation are present regardless of the brand architecture type, such that strategic investment in corporate reputation must be executed equally for all three categories of brand architecture.

Keywords: corporate reputation; brand architecture; monolithic brand structure; endorsed brand structure; branded identity structure; corporate identity; corporate brand; corporate communication; corporate culture; corporate reputation management; corporate social responsibility.

JEL: M310

DOI: $10.2478 / v 10033-011-0014-y$

\section{Introduction}

This paper will argue that corporate reputation has to be established and maintained independently and meticulously, regardless of the company's brand strategy, and thus even in the case of branded identity companies.

Corporate reputation has always been deemed a valuable corporate asset, but only since the late $20^{\text {th }}$ century has it become a business issue of the utmost importance. Corporate reputations are omnipresent, and no longer "seldom noticed until they are threatened" (Fombrun and Van Riel, 1997). They are acknowledged as one of the driving forces behind successful businesses. Reputations are externally perceived, and so are largely outside the direct control of a company's managers (Fombrun and Shanley, 1990; Fombrun and Van Riel, 1997). It takes time for a reputation to form in observers' minds. Empirical studies show that even when confronted with negative information, observers resist changing their reputational assessments (Wartick, 1992). Therefore, reputations are valuable intangible assets because they are inertial (Cramer \& Ruefli, 1994).

While most corporate reputation scholars agree that brand architecture is a part of the multidimensional paradigm of corporate reputation (Fombrun and Van Riel, 1997; Balmer and Greyser in 2007), the significance of its impact has yet to be agreed on (Dowling, 2001). Companies most frequently apply three types of branding strategies (Olins, 1978; Kotler, 1991; Fombrun and Van Riel, 1997): all products refer to the company, identifying the company name on all products (monolithic brand structure); combining the company name with product brand names (endorsed brand

*Dalija Hasanbegović

E-mail: dalijah@gmail.com 
structure) or individual names for all products without any explicit mention of the company (branded identity structure). Related to these branding strategies, some scholars do not acknowledge the symbiotic connection and interaction between brand architecture and corporate reputation (Zyglidopoulos, Alessandri, and Alessandri, 2006); while others claim that investing in corporate reputation for companies with separate freestanding brands (branded identity structure) is a waste of scarce resources (Brown and Dacin, 1997; Dawar and Parker, 1994).

This manuscript advocates the position that brands and corporate reputation are highly interrelated, as damage to the one harms the other. As a result, investing in corporate reputation for companies with branded identity structures is just as important for companies with monolithic brand architecture.

\section{Key Concepts and the World of Corporations Defined}

As defined by Cornelissen (2004) "corporate communications is the management function for the effective coordination of all means of communication with the overall purpose of establishing and maintaining a favorable reputation with stakeholder groups upon which the organization is dependent". This definition not only summarizes the essence of corporate communications, but describes a "favorable" reputation as its main goal. Nevertheless, corporate communications has to focus on the organization as a whole, not just on its external image, and create a "diagnostic and alteration capability" that will motivate the productivity of its internal structures as well (Van Riel and Fombrun, 2007).

In his definition of corporate communications, Blauw (1986) was among the first to add the notion of the corporate identity, stating that "Each item of corporate communication must convey and emphasize corporate identity." Thus, developing and managing a positive corporate reputation begins at the corporate identity level. Corporate identity is the "tangible manifestation of a corporate personality" (Olins, 1978), or a mix of an organization's distinctive, central and enduring characteristics (Albert and Whetten, 1985; Pratt and Foreman, 2000).

Yet in recent years this notion of a corporate identity as a monolithic phenomenon has been often replaced by a five identity ACCID Test (also referred to as $A C^{2} I D$ ) developed by corporate identity scholars Balmer and
Greyser in 2007. They define five different simultaneous corporate identities:

- Actual Identity constitutes the current internal and external, tangible and intangible characteristics of the corporation.

- Communicated Identity is disseminated through "controllable" corporate communication as well as "non-controllable" channels of communication.

- Conceived Identity is the general view of corporate image and corporate reputation held by relevant stakeholders.

- Ideal Identity is the optimal positioning of the firm in its market over a given time line based on systematic research and analysis.

- Desired Identity can be described as the vision corporate leaders have of the organization. While ideal identity is fact-based, the desired identity is frequently based on a CEO's subjective preferences.

In all of these, identity is closely related to the notion of corporate character, personality and culture. While companies do have multiple identities that simultaneously coexist, the potential risk to corporate reputation in a case of discrepancy or misalignment between any two identitities always has to be taken into consideration (Balmer and Greyser, 2007).

However, for a corporation to establish its corporate reputation, its corporate identity has to be projected onto a certain corporate image first. Corporate image (the majority of scholars use the terms corporate, public, external image and corporate brand interchangeably) is a collection of cognitive beliefs, emotions, ideas, and impressions a person or a group of stakeholders have about an organization (Dowling, 2001). Having a positive or poor public image is partially determined by signals that an organization transmits about itself; these signals are construed by stakeholders based on the firm's actions and self-expressions (Fombrun and Shanley, 1990). Nevertheless, there is no assurance that organizations with a clear corporate identity and sincere and engaging signals will create a positive image in the minds of all of their stakeholders (Van Riel and Fombrun, 2007). A number of factors influence the corporate image of an organization, among other things rumors, employee and management conduct, business decisions, social responsibility, crisis management, and both cognitive and irrational signal interpretations by its stakeholders (Van Riel and Fombrun, 2007). And just as there are multiple 
corporate identitities, a company can have multiple corporate images as well (Dowling, 2001).

Balmer and Greyser's (2007) definition directly ties corporate image and corporate reputation as two parts of a time line: "the perception of the organization by an individual, group or groups at one point in time (corporate image), and over time (corporate reputation)". Other scholars also concur that repeated impressions of corporate image over time structure corporate reputation (Zyglidopoulos, Alessandri, and Alessandri, 2006). Thus, corporate reputation can be defined as a "perceptual representation of a company's past actions and future prospects that describes the firm's overall appeal to all of its key constituencies when compared to other key rivals" (Fombrun, 1996).

According to Bromley (1993) corporate identity is analogous to personal identity or a notion of self-concept, while reputation is characterized as individual or corporate social identity. As such, reputation is related to many aspects of social psychology. Observed through Farr and Moscovici's (1984) study of social representation, which explains on what levels our understanding of the world is socially conditioned, and uniting distributive and collective views on social representation, reputation may also be described as the sum of members' beliefs about an entity (Bromley, 1993). The main difference between social and individual representation is in the fact that social representation is a collective outcome of social interaction (Farr and Moscovici, 1984).

Thus, corporate reputation as a corporate social identity to sociologists indicates legitimacy; reputation being a cumulative evaluation of a firm's performance related to institutional expectations and norms (Fombrun and Van Riel, 1998). In reality, companies have multiple characteristics and multiple reputations that develop from multiple but related corporate images among all of their stakeholders.

Aligned with everything stated thus far and before we embark on the main topic of this manuscript, which is defending the position that corporate reputation is a valuable asset not just for companies with monolithic and endorsed brand architecture, but also for those with freestanding individual brands operating under a corporate holding company, the key concepts used in this paper shall be defined as follows:

- Corporate Communication is a set of activities involved in managing and orchestrating all internal and external communications designed to create favorable points with the stakeholders upon whom the company depends (Van Riel and Fombrun, 2007).

- Corporate Reputation is a perceptual representation of a company's past actions and future prospects that describes the firm's overall appeal to all of its key stakeholders when compared to other key rivals in the market; and as such signals the firm's status within the industrial social system (Fomburn, 1996).

- Corporate Identity is a foundation for both the reputation and the brand (Oechsle, 2002). It represents those unique characteristics of an organization that its members understand as fundamental, distinctive and enduring within the organization over time (Pratt and Foreman, 2000).

- Corporate Culture is a total sum of the values, customs, traditions, meanings and representation that make an organization unique; it is thus often referred to as the "character of an organization". Those values embodied in corporate culture influence ethical standards within the organization as well as managerial behavior (Parker, 2000).

- Corporate Image is a holistic and ongoing public impression of an individual or a specific group (stakeholders) about a specific organization, formed directly or indirectly, with more or less awareness, rationally or emotionally, and which, as a rule, emerges as the positive or negative attitude/behavior of the public towards that organization (Alvesson, 1990).

- Corporate Brand is an umbrella for all of the company's product brands; it is correlated with corporate image and closely tied to corporate identity (Kitchen and Schultz, 2000). Due to its similarity, it is interchangeably used with the term corporate image.

- Brand Architecture is the explicit relationship between the corporate brand and the firm's various product brands developed as a result of a carefully established branding strategy (Zyglidopoulos, Alessandri, and Alessandri, 2006). These can have a monolithic, endorsed or branded-identity structure (Olins, 1978).

\section{Brand Architecture Explained}

Combining definitions of corporate communications and corporate reputation, it can be inferred that in order to "establish and maintain a favourable reputation" 
(Cornelissen, 2004) corporate communications aims to influence the perceptions of a firm's relevant stakeholders about the organization. The most popular academic and practical terms in describing stakeholders' perceptions are "brand", "corporate brand" and "brand image" (Van Riel and Fombrun, 2007).

The brand culture fits ideally with the era of the "global village" or "global theatre" (McLuhan, 1970). Brand and branding are creations of the commercial industry, but in the $21^{\text {st }}$ century "its impacts are virtually immeasurable in social and cultural terms" (Olins, 2003). There is a wide variety of the definitions for the term "brand"; one of the most encompassing is probably the one coined by the advertising expert David Ogilvy, who stated that a brand is "the intangible sum of a product's attributes: its name, packaging, and price, its history, its reputation, and the way it's advertised".

Brand image describes the specific composition of perceptions in the minds of stakeholders (Van Riel and Fombrun, 2007), therefore consisting of both the literal brand image and of the pattern of beliefs and feelings connected to the brand. As seen in the previous section, the terms corporate brand and corporate image are used interchangeably, and are closely tied to corporate identity.

Following Kitchen and Schultz's (2000) "corporate umbrella" analogy, corporate brand can be described as an umbrella for all of the other company product brands. A firm's branding strategy is the way the company presents itself to its stakeholders through its products and services (Zyglidopoulos, Alessandri, and Alessandri, 2006). Most scholars agree that branding strategy is tantamount to brand architecture, which "reflects the explicitness of the relationship between the corporate brand and the firm's product brands" (Zyglidopoulos, Alessandri, and Alessandri, 2006).

Olins (1978) distinguished three types of brand strategy on a continuum:

- The first end of the continuum is a corporate or monolithic brand structure where all the products and services are delivered under the same name and visual identity, thus equated with the corporate brand (Olins, 2003). Many reputable Far East companies have a tradition of using this type of brand strategy (Yamaha pianos, motorcycles, television sets; Mitsubishi cars, food, banks), but that trend is not geographically conditioned; perhaps the most notable example in the Western world is the broad spectrum of products and services of the Virgin Group conglomerate.

- At the middle of the continuum are companies with an "endorsed brand structure" (Olins, 2003). These companies have a number of brands with their own distinctive images and identities, but all of these sub-brands are linked to the corporate brand. One of the examples for this kind of brand structure is Nestle with its sub-brands (KitKat, Nesquik, Lion, and Nescafe among others).

- The final end of the continuum is represented by the branded identity structure where "each unit or brand is projected separately to the consumer and is seen to be completely independent" (Olins, 2003). Due to its emphasis on the product brand and omission of the corporate brand, this brand strategy is also known as the Procter \& Gamble approach in reference to their vast brand portfolio (Zyglidopoulos, Alessandri, and Alessandri, 2006). Other multinational companies with this type of brand structure are, among others, Unilever (with Rexona, SlimFast, Lipton, Knorr, etc), and premium alcoholic drinks business Diageo (with Guinness, Johnnie Walker, Baileys, Smirnoff, etc).

Even though the prominence of Olins' tripartite categorization of brand strategy from the late 1970s provides a useful basis for understanding corporate brand management, new times delivered more complex classifications. Thus Balmer (2002) after detailed research identified six contemporary corporate/trans-corporate types of brand structure. He contended that the traditional tripartite branding typology should be extended to reflect the new modes in which corporate brands were being utilized. Thus, they proposed six new corporate branding categories (Balmer and Greyser, 2007):

1. Familial-sharing of the same corporate brand by two entities within the same industry or sector (i.e. Hilton UK and Hilton USA);

2. Shared-similar to familial, but operating in distinct and sometimes related markets (i.e. Rolls Royce Aero Engineers UK and Rolls Royce Car Subsidiary of BMW);

3. Surrogate-a franchise agreement whereby one organization's product/services are branded as that of another (i.e. British Regional Airways use the British Airways Brand); 
4. Supra-a quasi-arch brand is used to supra-endorse company brands and is particularly common within the airline sector (i.e. "Star" Airline Alliance; "Miles \& More" Airline Alliance).

5. Multiplex-multiple uses and possibly multiple ownerships of a corporate brand among of a variety of entities in a variety of industry sectors (i.e. Virgin; Virgin Trains; Virgin Airlines; Virgin Financial Sector).

6. Federal-the creation of a new corporate brand by separate companies (i.e. the Airbus Consortium).

Although we deem it very important to be familiar with Balmer's (2002) typology of corporate brands and its multiple contemporary applications, for the purposes of this paper we shall continue working with Olins's tripartite categorization of brand strategy (2003).

The concept of brand architecture is crucial for the differentiation of firms, their marketing strategies and positioning, and it has been noted that the majority of companies pursue the prevailing brand structure attitudes of its sector (Balmer and Greyser, 2007).

While brand categorizations did evolve with the requirements of the new century, one notion remained unaffected: In the $21^{\text {st }}$ century, corporate reputation, regardless of the company's brand architecture, is the organization's most valuable intangible asset (Zyglidopoulos, Alessandri, and Alessandri, 2006).

\section{Corporate Reputation on the Stage of the "Global Theatre"}

The world of the $21^{\text {st }}$ century is McLuhan's "global village" categorized by the fast and accessible dissemination of information across continents, cultures, and markets. It is, moreover, a ferociously competitive marketplace. Firms have discovered that their stakeholders are increasingly savvy and determined in their desire to know more about a company behind the brand (Kitchen and Laurence, 2003). They want to "comprehend and critique social and ethical corporate performance" (Fombrun, 1996). To build, maintain and advance one's market position, brands and branding alone are insufficient (Kitchen and Laurence, 2003).

Consequently, empirical studies show that business leaders everywhere are recognizing corporate reputation as their company's most valuable intangible asset "which would take them longest to replace, if they were to start from scratch" (Zyglidopoulos, Alessandri, and Alessandri, 2006).
Fombrun's (1996) description of corporate reputation comprehensively reiterates its essence by stating that it "embodies the general estimation in which company is held by employees, customers, suppliers, distributors, competitors, and the public". By successfully fulfilling the expectations of each of these constituencies, the company develops "reputational capital" or intangible wealth that gives it a competitive lead against its rivals (Fombrun, 1996).

To build "reputational capital" or enhance its corporate reputation, companies are engaging in community activities and relationships that transcend both their basic goods production functions, and pure philanthropy. As Bromley (1993) noted "these extramural activities create the impression that the company upholds the values of the wider society, generating social approval and support". Businesses are no longer being assessed solely by their profits and balance sheets or their brand portfolios, but their positive impact on micro and macro communities, which has become a significant measure of their overall performance (Van Riel and Fombrun, 2007). Thus, investing in positive social impact builds toward a positive corporate reputation in return.

Empirical studies show corporate reputation to exponentially increase in importance since it creates a "reservoir of goodwill" in times of crisis (Fombrun, 2001), subsequently yields tangible financial benefits (Schnietz and Epstein, 2005), and places a company in a superior position against its competitors (Balmer and Greyser, 2007). Consistent with everything stated thus far, it can be summarized that corporate reputation symbolizes two essential aspects of a firm's efficiency: "an appraisal of its economic performance, and an appraisal of its success in fulfilling social responsibilities" (Etzioni, 1988).

The company that epitomizes Olins's (1978) branded corporate identity, the consumer products conglomerate Procter \& Gamble (P\&G), was among the first to acknowledge and foresee the hidden value of a favorable corporate reputation and to systematically and persistently invest in it. Since the early 1980s P\&G adapted its production, packaging, marketing and distribution techniques, and actively formed partnerships with schools, suppliers and customers to promote environmental issues. In 1990, P\&G established the Global Environmental Management Initiative (GEMI), a collaboration of 20 leading companies to support sustainable development. GEMI currently has 37 multinational member companies that share the same environmental codes of conduct, and support research 
on environmental matters (GEMl, 2007). Presently, P\&G is engaged in at least eight other projects involving environmental or philanthropic goals (Advertising Age, 2008).

As stated in the P\&G value statement "our reputation is earned by our conduct: what we say, what we do, the products we make, the services we provide and the way we act and treat others...as conscientious citizens and employees, we want to do what is right", and by persistently doing so they are traditionally annually named one of America's 10 Most Admired Companies by Fortune 500. Consistent with findings by McGuire, Sundgren, and Schneeweis (1988) that prior return on assets was highly correlated with a company's reputation for social responsibility, at the beginning of 2008 Procter $\&$ Gamble reported a $14 \%$ rise in profit and $9 \%$ rise in revenue, ranking first in its group (CNN Business, 2008). For Procter \& Gamble, having a vast portfolio of independent, individually reputable brands was not an obstacle for investing in corporate reputation as well.

\section{Conclusion}

To summarize all of the above, favorable corporate reputation does provide both tangible and intangible assets for a company. It entices investors, reduces the cost of capital, and augments a firm's competitive ability (Fombrun and Shanley, 1990). It also influences employees' construed external image of the company and enhances member identification, therefore influencing a strong "organizational citizenship behavior" within the organization (Dutton, Dukerich, and Harquail, 1994). Corporate reputations are externally perceived information signals originating from a unique corporate identity that enhance stakeholders' confidence in the firm's products and services (Balmer and Greyser, 2007). The other important characteristic of corporate reputations is that they are inertial, thus even if faced with negative information stakeholders oppose changing their reputational evaluation (Wartick, 1992).

Following the "actions speak louder than words" cliché analogy, it is not surprising that a company's behavior has been found to be the major influence on building, maintaining, advancing and enhancing the firm's reputation (Balmer and Greyser, 2007). Thus, by developing a corporate social responsibility strategy, companies aim to project themselves as "good corporate citizens", build a favorable reputation with their relevant stakeholders and their communities, and subsequently enjoy both the economic and non-economic benefits of doing so.

According to Kitchen and Laurence (2003), corporate reputation or "the management of the corporate brand," has an increasingly important role for a firm's ability to build and maintain its market position, attract and retain customers and skilled employees, and increase its market share in a global economy. Corporate reputations are developed over time, but can be changed or even destroyed as a result of short-term actions, whether deliberate or inadvertent (Fombrun and Shanley, 1990). Hence, business executives concentrate not only on finances, sales, and marketing, but increasingly on corporate reputation management as well through "exercising social responsibility and a due accountability for their actions" (Kitchen and Laurence, 2003). Based on numerous empirical studies conducted by corporate reputation scholars, this trend among business executives to exert increased focus on corporate reputation management will be anything but ephemeral.

Consequently, and as shown in this paper, persistent investment in corporate reputation should be preformed regardless of the company's brand architecture. As seen from the example of Procter \& Gamble's, even for companies with a branded identity structure investing in corporate reputation is a shrewd business decision, and never a waste of scarce resources. In a world of global brands, global corporations, as well as global news and global information flows, faced with increasingly savvy and demanding customers, the whole has definitely became greater than the sum of its parts in the corporate world. Corporate reputation takes precedence over individual brand reputation as an "umbrella" for all of its freestanding brands, and therefore should in all instances be given priority. $[$.

\section{References}

Advertising Age (2008). "Unilever, P\&G War Over Which is Most Ethical." March 03.

Albert, S., and Whetten, D. (1985). Organizational Identity. In L.L. Cummings and B. M. Shaw (eds.)., Research in Organizational Behaviour. Greenwich: JAI Press.

Alvesson, M. (1990). Organization: From substance to Image? Organization Studies, Vol. 11, No. 3, pp. 373-394.

Balmer, J. M. T., (2002). "Corporate Brands Ten Years On: What's New?" Bradford School of Management: The Working Paper Series, number 02/07.

Balmer, J. M. And Greyser, S.A. (eds.) (2007). Revealing the Corporation: perspectives on identity, image, reputation, corporate branding, and corporate-level marketing. New York: Routledge 
Bearden, W.O. and Shimp, T.A. (1982). The Use of Extrinsic Cues to Facilitate Product Adoption. Journal of Marketing Research, 19: 229-239.

Blauw, E. (1986). Het Corporate Image: Beeldvorming van de Onderneming. Amsterdam: De Viergang.

Bromley, D.B. (1993). Reputation, Image and Impression Management. New York: John Wiley \& Sons.

Brown, T.J. and Dacin, P.A. (1997). 'The Company and the Product: Corporate Associations and Consumer Product Responses', Journal of Marketing, January, 1997, vol. 61, pp. 64-84

CNN Business (2008). Stock Market Report. January 14.

Cornelissen, J. (2004). Corporate Communications: Theory and Practice. New York: Sage Publications.

Cramer, S. \& Ruefli, T. (1994) 'Corporate reputation dynamics: Reputation inertia, reputation risk, and reputation prospect', Paper presented at the National Academy of Management Meetings, Dallas.

Dawar, N. and Parker, P. (1994). 'Marketing universals: consumers' use of brand name, price, physical appearance, and retailer reputation as signals of product quality, Journal of Marketing, 58, 2, pp. 88-95.

Doorley, J. And Garcia, H. F. (2007). Reputation Management. New York: Routledge.

Dowling, G. (2001). Creating Corporate Reputations: Identity, Image, and Performance. Oxford: Oxford University Press.

Dutton, J. E., Dukerich, J. M., and Harquail, C.V. (1994). Organizational Images and Member Identification. Administrative Science Quarterly, 39: 239-263.

Etzioni, A. (1988). The Moral Dimension. New York: Free Press.

Farr, R. And Moscovici, S. (eds.) (1984). Social Representations. Cambridge: Cambridge University Press.

Fombrun, C.J. and Shanely, M. (1990). "What's in a name? Reputation Building and Corporate Strategy." Academy of Management Journal, 33: 233-258.

Fombrun, C. J. (1996). Reputation: Realizing Value for the Corporate Image. Boston: Harvard Business School Press.

Fombrun, C.J., and Van Riel, C. B. M. (1997). The Reputational Landscape. Corporate Reputation Review, 1(5): 5-13.

Fombrun, C. J. (2001). Corporate Reputations as Economic Assets. Handbook of Strategic Management. Oxford: Blackwell.

Fortune 500 (2008). America's Most Admired Companies. March 03.

Goldberg, M.E. and Hartwick, J. (1990). "The effects of advertiser reputation and extremity of advertising claim on advertising effectiveness." Journal of Consumer Research, 17: 172-179.

Goffman, E. (1959). The Presentation of Self in Everyday Life. New York: Doubleday.

Kitchen, P. J., and Schultz, D. E. (2001). Raising the Corporate Umbrella: Corporate Communications in the $21^{\text {st }}$ Century. London: Palgrave.

Kitchen, P. J., and Laurence, A. (2003). Corporate Reputation: An Eight-Country Analysis. Corporate Reputation Review, 6(3): 103-117.

Kydd, C.T., Ogilvie, J.R. and Slade, L.A. (1990). "I do not care what they say, as long as they spell my name right: Publicity, Reputation and Turnover." Group and Organization Studies, 15: 53-74.

McGuire, J., Sundgren, A., and Schneeweiss, T. (1988). Corporate Social Responsibility and Firm Financial Performance. Academy of Management Journal, 31: 854-872.

McLuhan, M. (1970). From Cliche to Archetype. New York: Pocket Books

McNeil, K. and Miller, R. E. (1980). "The profitability of consumer protection: warranty policy into auto industry." Administrative Science Quarterly, 25: 407-427.
Oechsle, S.J. (2002). Brands and broadband.A communications opportunity. Corporate Reputation Review, Vol. 5, No. 2-3, pp.176-191;

Olins, W. (1978). The Corporate Personality. An Inquiry into the Nature of Corporate Identity. London: Design Council.

Olins, W. (1990). Corporate Identity: Making Business Strategy Visible Through Design. New York: McGraw-Hill.

Olins, W. (2003). Wally Olins on Brand. London: Thames \& Hudson Ltd.

Parker, M. (2000) Organizational Culture and Identity, London: Sage

Pratt, M.G. and Foreman, P.O. (2000) "Classifiying managerial responses to multiple organizational identities", Academy of Management Review, 25 (1): 18-42.

Schietz, K. E., and Epstein, M. J. (2005). Exploring the Financial Value of a Reputation for Corporate Social Responsibility During a Crisis. Corporate Reputation Review, 7(4): 327-345.

Van Riel, C. B. M., and Fombrun, C. J. (2007). Essentials of Corporate Communication: implementing practices for effective reputation management. London: Routledge.

Zyglidopoulos, S. C., Alessandri, S. W., and Alessandri, T. M. (2006). Reputation, Image, Identity, and Competitiveness. New York: Reputation Institute.

Wartick, S. L. (1992). "The Relationship between intense media exposure and change in corporate relationship." Business and Society, 31: 33-49. 